\title{
Macrophage Cell-Cell Interactions Promoting HIV-1 Infection
}

\author{
Maeva Dupont * and Quentin James Sattentau * \\ The Sir William Dunn School of Pathology, The University of Oxford, Oxford OX13RE, UK \\ * Correspondence: maeva.dupont@path.ox.ac.uk (M.D.); quentin.sattentau@path.ox.ac.uk (Q.J.S.)
}

Received: 3 April 2020; Accepted: 27 April 2020; Published: 28 April 2020

\begin{abstract}
Many pathogens infect macrophages as part of their intracellular life cycle. This is particularly true for viruses, of which HIV-1 is one of the best studied. HIV-1 infection of macrophages has important consequences for viral persistence and pathogenesis, but the mechanisms of macrophage infection remain to be fully elucidated. Despite expressing viral entry receptors, macrophages are inefficiently infected by cell-free HIV-1 virions, whereas direct cell-cell spread is more efficient. Different modes of cell-cell spread have been described, including the uptake by macrophages of infected $\mathrm{T}$ cells and the fusion of infected $\mathrm{T}$ cells with macrophages, both leading to macrophage infection. Cell-cell spread can also transmit HIV-1 between macrophages and from macrophages to T cells. Here, we describe the current state of the field concerning the cell-cell spread of HIV-1 to and from macrophages, discuss mechanisms, and highlight potential in vivo relevance.
\end{abstract}

Keywords: HIV-1; macrophage; T cell; virological synapse; phagocytosis; cell-cell fusion; nanotubes

\section{Introduction}

Macrophages are tissue-embedded cells of the innate immune system that have two distinct origins, primitive yolk sac-derived or infiltrating blood monocyte-derived cells [1]. They have essential roles in eliminating dead and dying cells, remodelling and repairing tissues, and eliminating pathogens and pathogen-infected cells. However, macrophages are also host cells for a variety of viral, bacterial, and parasitic pathogens [2]. These microorganisms must find mechanisms to enter and persist in macrophages, whilst avoiding the array of anti-microbial defenses intrinsic to these cells. Thus, the active routes of uptake by macrophages-phagocytosis, endocytosis, or macropinocytosis-usually evolve into degradative compartments-phagolysosomes, endolysosomes or autophagolysosomes [3]. Microorganisms may therefore avoid degradation by inhibiting phagosome/endosome maturation, residing in non-degradative quasi-intracellular compartments [4], or escaping into the cytoplasm [5]. A final altruistic defense is macrophage programmed cell death, either anti-inflammatory by apoptosis or pro-inflammatory by pyroptosis or necroptosis, to prevent ongoing pathogen replication and dissemination [6]. Pathogens, of which bacteria are the best studied group, have therefore evolved a sophisticated approach to evade these defences and invade, survive, proliferate in, and disseminate from, macrophages $[2,5,7,8]$.

The human immunodeficiency virus type-1 (HIV-1) infects cells that express the viral receptors CD4 and one of the chemokine receptors CCR5 or CXCR4 [9]. Despite early reports of the HIV-1 infection of receptor-negative cell types, these have generally not been confirmed, with the potential exception of astrocytes that continue to be described as permissive targets for HIV-1, despite lacking conventional entry receptors $[10,11]$. HIV-1 strains that use CCR5 are associated with transmission between individuals and all later stages of viral infection, whereas CXCR4-using strains are more associated with later stage infection in a proportion of infected individuals [12]. T helper cells express high levels of $\mathrm{CD} 4$, and, once activated by cognate antigen exposure, also express CCR5, and are therefore 
highly susceptible to HIV-1 infection [12]. By contrast, myeloid lineage cells including monocytes, macrophages, and dendritic cells (DC) express low levels of CD4 and CCR5 or CXCR4, and are less efficiently infected by HIV-1 [12,13]. Myeloid-lineage cells also constitutively express antiviral restriction factors that potently reduce HIV-1 replication post-entry [14]. As a result, macrophages are inefficiently infectable by most viral clones in vitro, in line with the observation that so-called "macrophage-tropic" viruses, which have a higher affinity for CD4 than their non-macrophage-tropic counterparts, only arise relatively late in in vivo infection $[12,13]$. An extreme example of limited HIV-1 macrophage infection relates to transmitted/founder (T/F) infectious molecular clones that infect monocyte-derived macrophages (MDM) poorly or not at all, in strong contrast to primary $\mathrm{CD} 4^{+} \mathrm{T}$ cells that were robustly infected $[15,16]$. In quantitative terms, T/F viruses were on average $>1000$-fold more infectious for $\mathrm{T}$ cells than macrophages, and even so-called macrophage-tropic viral clones were $\sim 10$-fold less infectious for macrophages than T cells $[15,16]$. However, a caveat is that most work on macrophage infection has been carried out using cell-free virus infection. Given that macrophages are tissue-resident cells that interact with each other, and with lymphocytes in their antigen-presenting capacity, it seems logical that forms of cell-to-cell spread might be particularly relevant to in vivo viral dissemination.

\section{Modes of HIV-1 Cell-Cell Spread}

The fluid phase diffusion of cell-free virus particles is an inefficient mode of cell infection, since virions must encounter target cells amongst a variety of non-permissive cell types, engage the cell surface, locate entry receptors, and fuse, all in the face of soluble anti-viral host defences [17].

By contrast with cell-free spread, cell-cell HIV-1 infectious spread between T cells is generally accepted to be approximately 10-fold more efficient [18,19], although higher estimates have been reported based mainly on transfer of the viral protein Gag between cells [17]. Cell-cell spread can overcome many of the obstacles to viral infection, as follows: 1 . Because infected and uninfected target cells are physically engaged, virus does not have to navigate long-distance fluid phase diffusion to engage its target cell [18]. 2. Viral budding may be polarized towards the cell-cell contact site, focusing viral release towards the closely opposed target cell [20]. 3. The viral receptors cluster at the site of cell-cell contact, allowing rapid viral receptor engagement and entry [21]. 4. The high viral multiplicity of infection (MOI) imparted by cell-cell spread may assist the virus in overcoming restriction factor antagonism [22,23], and may additionally increase resistance to neutralizing antibodies against specific epitope clusters [24,25] and some, but not all, antiretroviral therapy (ART) [26-28]. The first mechanism of HIV-1 cell-cell spread was described for T cells, and introduced the concept of the virological synapse (VS, Figure 1) [21]. The T cell VS relied upon viral hijacking of the actin cytoskeleton, microtubule network and secretory apparatus in the infected cell to promote polarized viral budding, and of the actin cytoskeleton, adhesion molecules (e.g., ICAM-1, ICAM-3, and LFA-1) and viral receptors in the target cells to promote receptor clustering at the site of cell-cell interaction $[17,29,30]$ (Figure 1). However, unlike the T cell VS, which is a pathogen-induced structure (since normal T cells only make very transient contacts with each other [31]), antigen presenting cell-T cell immunological synapses are part of the intrinsic function of these cells, and so might be expected to occur more readily in infected tissues. Indeed, DC-T cell clusters were first described in this regard, with highly productive $\mathrm{T}$ cell infection observed in coculture with HIV-1-infected DCs [32]. Two types of transfer from DCs to T cells have been described. The first is infection in cis, in which DCs and macrophages are infected by HIV-1 and release the virus to infect adherent T cells across a structure termed an "infectious synapse". The second is infection in trans, by which HIV-1 is taken up via lectin-mediated interactions, such as by the Siglec-1 and DC-SIGN-mediated uptake [33], into a non-degradative intracellular compartment, which can then be released to infect adherent $T$ cells [34]. This type of cell-cell in trans viral transfer event has been confirmed using intravital microscopy in mice: sinus-lining macrophages captured retroviral particles via Siglec-1 and transferred them in trans to susceptible lymphocytes [35]. Interestingly both the in cis and in trans infection routes appear to rely upon virus storage in a non-degradative 
compartment prior to release to infect $\mathrm{T}$ cells. Although not formally demonstrated, it seems likely that the virus-containing compartments (VCC) described for MDM implicated in in cis infection, and DCs in in trans infection, are the same or related membranous structures $[4,36]$.

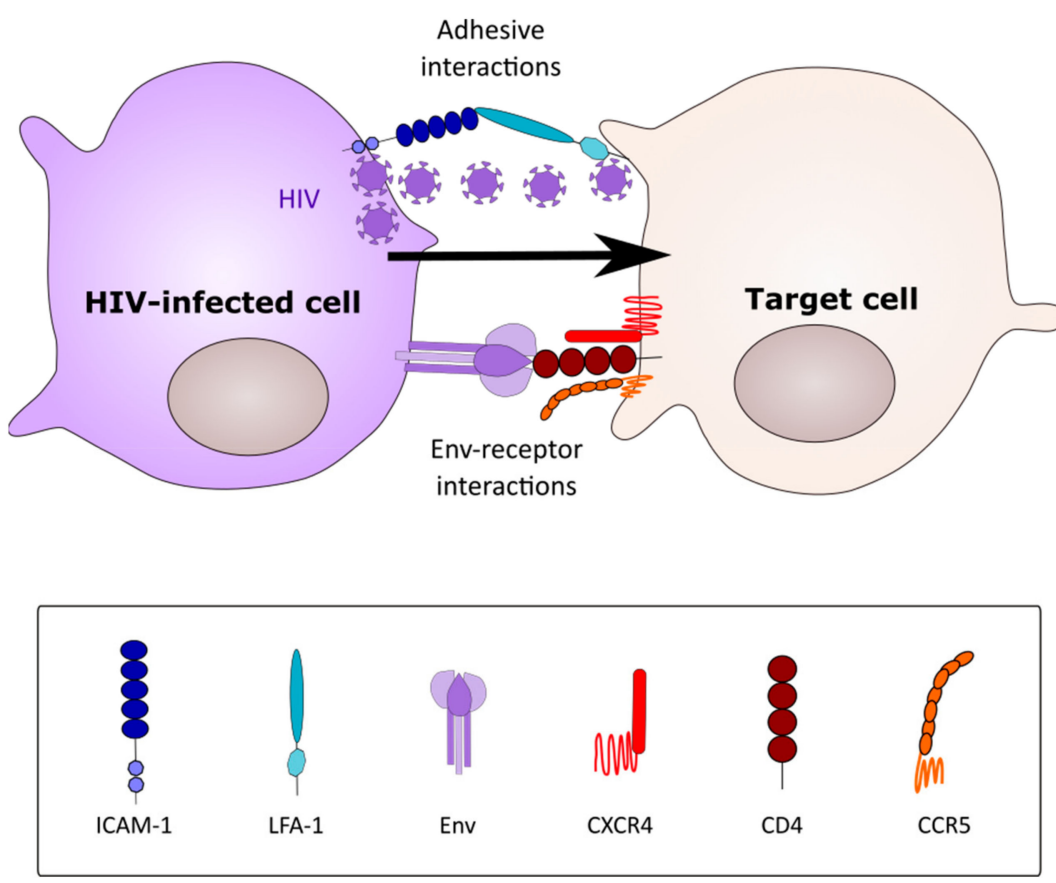

Figure 1. A prototypical virological synapse. The infected cell $\left(\mathrm{CD} 4^{+} \mathrm{T}\right.$ cell or macrophage) forms a transient adhesive contact with a receptor-expressing target cell via Env-CD4 interactions $\left(\mathrm{CD} 4^{+} \mathrm{T}\right.$ cell-T cell synapses) or via adhesion molecule interactions (macrophage- $\mathrm{CD} 4^{+} \mathrm{T}$ cell synapse). Virus buds from the infected cell and migrates towards receptors clustered on the target cells (arrow). Infection follows via conventional receptor-mediated entry.

\section{The Macrophage Virus-Containing Compartment}

Insight into the cell biology of macrophage infection by HIV-1 has come from analysis of the compartment into which HIV-1 buds, and is subsequently released. Early electron microscopy studies observed virions accumulated in apparently intracellular compartments within macrophages [37,38], that were initially proposed to be multivesicular bodies (MVB), based upon morphology and phenotype [39]. However, subsequent analysis revealed that these vesicular structures were in fact surface-connected and at neutral $\mathrm{pH}$ [40-42], and therefore were a non-degradative compartment, within which HIV-1 could remain infectious for extended periods of time. This was proposed to be up to 7 weeks post-infection in one study [43], although this length of time might be confounded by very low level ongoing viral replication in the presence of inhibitor. Connections linking the VCC to the surface were frequently tight $(\sim 20 \mathrm{~nm})$, and therefore too small for free diffusion of virions or antibodies, thereby protecting the virus from hostile elements of humoral immunity [4,44-46]. Live-cell imaging revealed that some VCC were open to the extra-cellular milieu, and could be accessed by small dextran particles after HIV-1 infection. However, not all VCC remained cell surface-connected, some conduits being transient and allowing or not the diffusion of small molecules in and/or out these compartments [47]. The origins of VCC remain unclear, as this structure is pleomorphic [42] and presents markers specific for the plasma membrane (e.g., CD44), but also of MVB (e.g., CD9, CD81, CD53) $[39,41]$. It was subsequently established that HIV-1 subverts a pre-existing compartment in macrophages to form the VCC. Following infection of MDM, viral Gag is recruited to pre-existing $\mathrm{CD}^{+}{ }^{+}$compartments, which become VCC [42,48]. Additionally, lectins such as Siglec-1 can play an important role in VCC formation and function. A recent study demonstrated that VCC formation does not necessarily require macrophage infection, since the Siglec-1 capture of non-infectious viral-like 
particles (VLP) bearing HIV-Env and gangliosides also led to VCC formation [49]. Depletion of Siglec-1 from infected macrophages decreased VLP uptake, significantly reduced VCC volume, and reduced the transfer of particles to autologous T cells, confirming that VCC are important structures for viral transfer between infected macrophages and T cells [49]. The budding of HIV-1 into this type of compartment is in striking contrast to the plasma membrane budding of the virus in T cells, which allows full access of antibodies to cell surface-exposed virions. Engagement of macrophages by T cells might signal to activate actin-mediated delivery of virus from the VCC to the engaged lymphocyte. This hypothesis is supported by the observation that the viral protein Gag and tetraspanins, previously described as markers of MVB but corresponding to the VCC [39], were concentrated at the VS between infected MDM and uninfected T cells, with about $80 \%$ of the Gag staining located in the synapse [50]. As opposed to the T cell-T cell VS, the recruitment of Gag to the MDM-T cell VS was independent of Env, but could be prevented when the Pr55Gag matrix protein was mutated [50]. The movement of the $\mathrm{Gag}^{+}$ compartment towards the VS is most likely dynamic and targeted, and was shown to rely on the microtubule network and on the kinesin KIF3A [51]. Indeed, when KIF3A was silenced by RNAi in MDM, Gag ${ }^{+}$VCC accumulated in the cytoplasm, while the release of HIV-1 virions in the culture supernatant was significantly reduced, indicating that the actin/microtubule cytoskeleton is essential in directing $\mathrm{Gag}^{+}$VCC towards the plasma membrane and allowing virus release, notably at the VS [51]. Interestingly, this process of enhanced T cell infection through VCC-containing HIV-1 particles may depend on VCC phenotype. Thus, when HIV-1 was within CD36 ${ }^{+}$VCC, the knockdown of CD36 by RNA interference or inhibition by soluble anti-CD36 antibodies prevented the release of HIV-1 particles from infected macrophages, and consequently their transfer to $\mathrm{CD} 4^{+}$target $\mathrm{T}$ cells [48].

Adding in vivo relevance to the idea of HIV-1-containing VCC, Ganor and colleagues reported that macrophages isolated from urethral tissue of HIV-1-infected men under cART contained HIV-1 DNA, RNA, protein, and virions in a VCC-like compartment. By contrast, viral components were undetectable in urethral $\mathrm{T}$ cells, highlighting the potential importance of macrophages as viral reservoirs in specific mucosal tissues [52].

\section{4. $\mathrm{CD}^{+} \mathrm{T}$ Cell Infection by Spread from Macrophages}

Similar to the infectious synapses described between DCs and T cells [34], macrophages can transfer high multiplicity infectious HIV-1 to T cells via transient adhesive synapses. The initial descriptions of this showed convincing transfer of infection from the infected macrophages to the primary $\mathrm{CD} 4^{+} \mathrm{T}$ cells $[43,53,54]$. Subsequent analyses revealed that the T cells adhered to the HIV-1-infected MDM, CD4 colocalized to the interface, and HIV-1 was rapidly transferred to the T cell [55]. Extended coculture of infected macrophages with the T cells led to $>10 \%$ of the entire $\mathrm{T}$ cell culture becoming $\mathrm{Gag}^{+}$within $12 \mathrm{~h}$ [55]. In a contemporaneous study, transfer of GFP-labelled Gag from the infected MDM to T cells was shown by live cell imaging, confirming the dynamic nature of this interaction [50]. Later live cell studies revealed how individual infected macrophages may productively infect large numbers of $\mathrm{T}$ cells in culture in an actin and adhesion molecule (ICAM-1-LFA-1)-dependent manner [56] (Figure 2A).

Cell-cell spread from the MDM to T cells was not only efficient, but reduced the impact of reverse transcriptase (RT) inhibitors and some broadly neutralizing antibodies (bNAbs) on HIV-1 infection [26], similar to that observed for T cell-T cell spread [56]. Interestingly, the effect of MDM to T cell spread was highly selective for antibody inhibition, in that bNAbs targeting the gp41 membrane proximal external region (MPER) were ineffective, whereas those targeting the CD4 binding site and V3 loop-glycan epitope cluster remained potent. Reasons for this may have been at least partially steric, since Fab fragments of MPER-specific bNAbs regained neutralizing activity [56]. Impaired RT inhibitor activity appeared to be due to the high multiplicity of infection via the cell-cell route, since increasing the MOI of cell-free virus yielded similar resistance to RT inhibitors [26]. This result is in accord with the model first suggested by the Baltimore lab studying T cell-T cell spread, that high MOI infection can overcome limiting intracellular levels of RT inhibitor [27]. Additional to the highly efficient $\mathrm{T}$ cell infection route, MDM-mediated transfer of HIV-1 to T cells may help to seed the $\mathrm{CD} 4^{+}$memory latent 
reservoir. Upon HIV-1 infection, MDM secrete a pool of cytokines and chemokines, which attract CD4 ${ }^{+}$ $\mathrm{T}$ target cells, potentially creating an ideal situation for viral dissemination [57], and DCs may assist in viral latency induction in $\mathrm{CD}^{+}{ }^{+} \mathrm{T}$ cells during cell-cell HIV-1 transfer [58-61].

Macrophage phenotype is highly influenced by cytokine environment, and differentiation of MDM into "classically activated" (M1) or "alternatively activated" (M2a, M2b, M2c) MDM has profound influence on sensitivity to HIV-1 infection [62]. Moreover, macrophage phenotype has implications for function in terms of HIV-1 cell-cell spread. MDM differentiated in the presence of IL-4 (termed M-4) were found to be more sensitive to HIV-1 infection, and to subsequent dissemination of HIV-1 to T cells, than MDM differentiated in IL-13 (M-13) [63]. MDM differentiated to M1 in the presence of IFN- $\gamma$ and TNF- $\alpha$, or M2a in the presence of IL-4, reduced or enhanced expression of DC-SIGN respectively, which in turn modulated sensitivity to HIV-1 infection and dissemination to T cells [64], highlighting the role of DC-SIGN and related adhesion factors in HIV-1 spread. A recent analysis of macrophage phenotype in ex vivo urethral tissues [52] revealed a switch from a predominantly M1 phenotype in uninfected individuals to an intermediate (Mi) in infected, ART-suppressed individuals, implying that Mi polarization may facilitate HIV-1 reservoir formation.

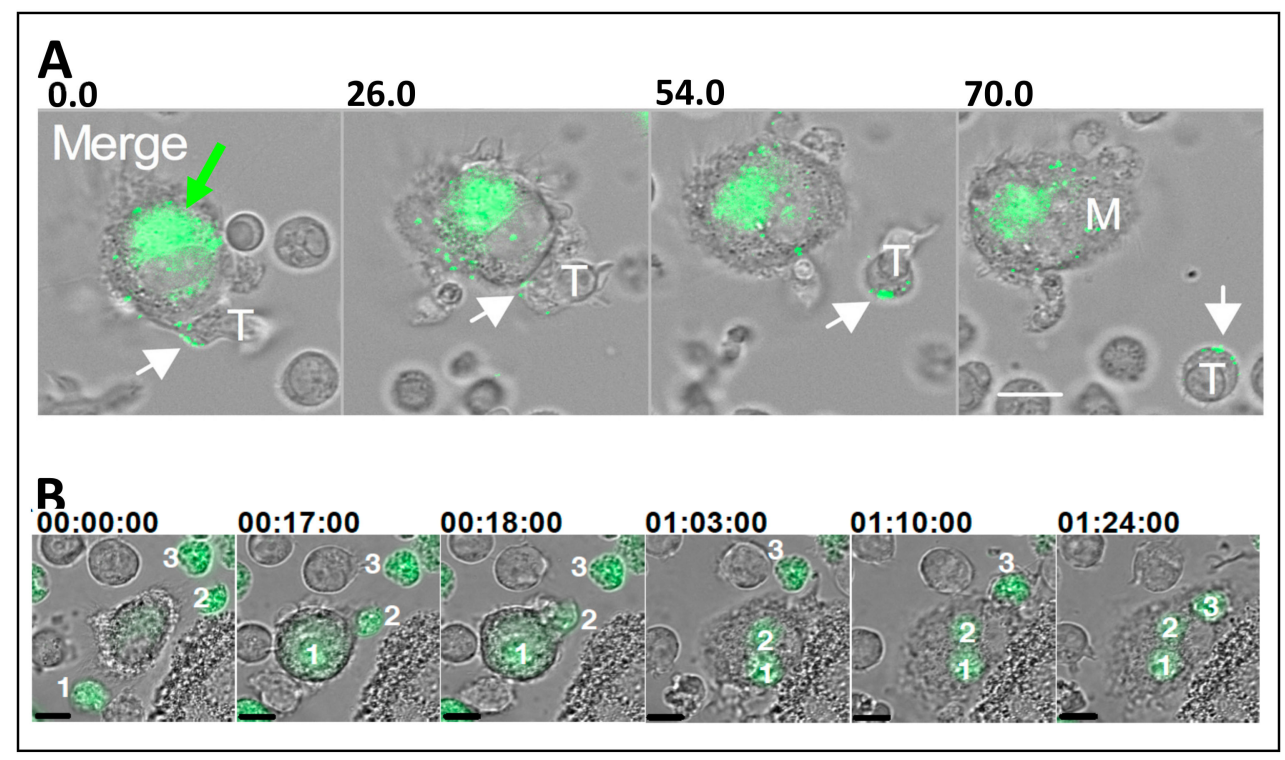

Figure 2. HIV-1 transfer between macrophages and CD4 ${ }^{+}$T cells. (A) HIV-1 infected macrophages transfer GFP-HIV-1 to a CD4+ T cell that is scanning the macrophage surface via transient adhesive interactions (taken from [56]). The green arrow indicates the virus-containing compartment. The white arrows show viral particles engaged with the $\mathrm{T}$ cell surface. Numbers above images represent minutes:seconds after initiating coculture. Scale bar $=10 \mu \mathrm{m}$. (B) HIV-1-GFP infected CD4 ${ }^{+} \mathrm{T}$ cells being engulfed by a macrophage (taken from [65]). Numbers above images represent hours:minutes:seconds. Scale bar $=10 \mu \mathrm{m}$.

\section{Macrophage Infection by Phagocytic Uptake of HIV-1-Infected CD4 ${ }^{+}$T Cells.}

As described above, macrophage infection by cell-free HIV-1 is inefficient, particularly for viruses that initiate infection in a new host, T/F viruses [15]. However, macrophage infection by two distinct forms of cell-cell spread has been described recently. The first was discovered when HIV-1-infected $\mathrm{T}$ cell lines or primary $\mathrm{T}$ cells were cocultured with autologous MDM. The MDM were observed by live cell immunofluorescence microscopy to engulf preferentially the infected T cells, compared to their uninfected counterparts (Figure 2B) [65]. This was then quantified by multispectral flow imaging (Imagestream ${ }^{\mathrm{TM}}$ ), and macrophages were observed to engulf approximately 50-fold more dying infected $T$ cells than healthy uninfected cells [65]. Rather than elimination of the infected $\mathrm{T}$ cell in a phagolysosome, uptake of virally infected $\mathrm{T}$ cells resulted in rapid viral spread from the $\mathrm{T}$ cells to MDM, which became productively infected. This efficient mode of infection was true 
even in the context of weakly-macrophage tropic T/F virus clones [65]. However, despite the robust nature of infection resulting from transfer of the virus from infected $\mathrm{T}$ cells, this did not overcome intrinsic tropic restrictions, since MDM engulfment of X4 "T cell-tropic" virus-infected T cells did not infect the MDM [65]. Thus, virus infection of MDM used the conventional route of CD4 and CCR5-mediated entry [65]. The "eat-me" signals for MDM exposed on HIV-1-infected T cells have yet to be elucidated, but do not appear to be the more common signals associated with apoptotic cell uptake by phagocytes, as a panel of efferocytosis inhibitors failed to significantly reduce HIV-1-infected T cell uptake by MDM [65]. This was the first description of a "phagocytic" VS, and joins the small number of other phagocytic structures implicated in pathogen cell-cell spread, including bacteria [66,67] and parasites [68], and may therefore represent a general mode of pathogen dissemination [69].

\section{Potential Consequences of Phagocytic Uptake of HIV-1 Infected Cells}

All modes of cell-cell infection described above rely upon viral fusion with the target cell using CD4 and a chemokine receptor, regardless of the virus producer or the target cell type. It was therefore puzzling that a large body of literature describes human astrocyte infection, despite the fact that these cells do not appear to express CD4 or CCR5, at least in culture [70-73]. Equally difficult to explain is the well-documented finding that transfection or transduction of the HIV-1 genome into astrocytes, bypassing the limiting entry step, leads to productive viral replication in astrocytes [74-76]. How does HIV-1 infect cells that lack conventional entry receptors, and then fail to yield a productive infection in otherwise permissive cells? One explanation for this may come from the observation that astrocytes are endocytic and phagocytic and are capable of internalizing virions and engulfing cell debris from their surroundings into a non-degrading compartment [77-79]. Using sensitive viral entry assays, we confirmed the absence of HIV-1 fusion with astrocytes, and then went on to show that astrocytes make intimate contacts with HIV-1-infected MDM, and engulf virus-containing cell debris from these cells [70]. This leads to positive signals for viral infection in cells that are otherwise not productively infected, since the astrocytes will contain viral proteins and nucleic acids. Whilst these results do not formally exclude low-level infection of a small percentage of astrocytes by an unconventional entry mechanism, they do provide an explanation additional to the endocytic capacity of astrocytes [80] for the apparent observation of infected astrocytes, when exposed to the virus or virally-infected cells in vitro and in vivo [81,82]. A similar explanation may also apply to the observations that a small percentage of monocytes isolated from HIV-1-infected individuals contain nucleic acid signals for both HIV-1 and the T cell receptor [83]. Since monocytes are considered to be relatively resistant to HIV-1 infection as a result of high levels of restriction factor expression, their ability to phagocytose HIV-1-infected cells and their debris may contribute to false positive infection signals [84].

\section{Fusion between HIV-1-Infected $\mathrm{CD}^{+}{ }^{+} \mathrm{T}$ Cells and Macrophages}

HIV-1-induced fusion of T cells with macrophages has been evoked as a mode of viral spread between these cell types that may occur in parallel with VS-mediated viral spread [85], similar to the early work by the Steinman lab on DC-T cell syncytium formation driven by HIV-1 infection [32,86]. Env-mediated fusion between monocytic and T cell lines revealed that the ensuing heterokaryons were viable, stable, and presented a dominant activated monocyte-like phenotype [87]. Revisiting the concept of myeloid-T cell fusion more recently [88], coculture between acutely HIV-1-infected activated CD4 ${ }^{+}$ $\mathrm{T}$ cells and MDM culminated in the rapid appearance of $\mathrm{Gag}^{+}$multinucleated MDM that expressed phenotypic T cell markers (CD2, CD3, Lck), and which was prevented by HIV-1 fusion inhibitors. Infected MDM subsequently fused with adjacent MDM, and the resulting strongly $\mathrm{Gag}^{+}$multinucleate heterokaryons were viable, and released the virus for at least one month [88]. The authors did not observe obvious phagocytic uptake of HIV-1-infected T cells, and proposed the explanation that because the T cells were infected for only 3 days, T cells did not expose efferocytic "eat-me" signals, but did express high levels of the plasma membrane Env, mediating cell-cell fusion. An additional aspect of the formation of MDM-T cell heterokaryons is that the incorporation of T cell plasma membrane 
into the MDM appeared to allow rapid budding of virus at the heterokaryon plasma membrane, probably accounting for the subsequent MDM-MDM fusion. This is in contrast to the normal budding profile of macrophages into VCC-like compartments, which would presumably prevent MDM-MDM fusion $[4,39,89]$, and suggests that $\mathrm{T}$ cell derived $\mathrm{PIP}_{2}$ might remain located at the heterokaryon plasma membrane, transiently refocusing viral budding to this site. The infected $\mathrm{T}$ cell fusion observation was extended to immature DCs and osteoclasts, implying a general mechanism of HIV-1 dissemination between T cells and myeloid-lineage cells [90]. Intriguingly, the heterokaryons formed between MDM at least partially overcame the restriction imposed on myeloid cells by SAMHD1 [90]. It was suggested that merging of the $\mathrm{T}$ cell cytoplasm with that of the MDM would transfer cyclin/CDK components and dNTPs that might inactivate/saturate SAMHD1 activity, and/or that the T cell nucleus containing integrated provirus may continue to transcribe viral DNA within the heterokaryon, bypassing the reverse transcription antagonism imparted by SAMHD1 [90]. Since multinucleated macrophages have been described in vivo, it seems likely that this process has biological significance, particularly in the brain where microglia and perivascular macrophages are infected [91], and in immune tissues where myeloid and T cells are in close proximity such as lymph nodes, tonsils, spleen, and gut-associated lymphoid tissue.

\section{HIV-1 Spread between Macrophages: Implication of Tunneling Nanotubes.}

Tunneling nanotubes (TNT) are a novel type of cell-to-cell communication machinery, allowing distant cells from different lineage—-for example immune cells and neuronal cells [92] - to exchange information about their environment. They are F-actin rich structures connecting at least two cells without touching the substrate in 2-dimensional cultures in vitro, which allow the transport of calcium flux, genetic material, proteins, and organelles, including lysosomes and mitochondria, between distant cells, up to $200 \mu \mathrm{m}$ apart [93-95]. Interestingly, TNT can be either open-ended, allowing for the direct transfer of cytoplasm content, or close-ended and conjugated with a Gap-junction, which allows them to fulfil their transfer function $[95,96]$. In macrophages, thin TNT (often short, with a diameter of less than $0.7 \mu \mathrm{m}$ ) that contain only F-actin can be distinguished from thick TNT (or long, with a diameter above $0.7 \mu \mathrm{m}$ ), which comprise both F-actin and microtubules [93]. These structures are hijacked by pathogens, specifically HIV-1, which triggers TNT formation in human MDM without altering their length [97]. Eugenin and colleagues proposed that short TNT could transport single HIV-1 particles, while long TNT may carry larger HIV-1-containing vesicles (e.g., exosomes or VCC), either within or on the outside of the nanotube [97]. However, endosome, Golgi and endoplasmic reticulum proteins (ER) components were found in the proteome of TNT, and were associated with HIV-1 Gag and Env proteins, suggesting that endocytosed HIV-1 was transported to the ER and Golgi apparatus before being transported into TNT $[98,99]$. In addition, HIV-1-related Rab11 ${ }^{+}$endosome compartments were found to traffic through TNT between human MDM, in a myosin-II and actin-dependent manner [98]. In a recent study, connexin 43 , a component of the gap junction, was found to accumulate in intracellular compartments that localized both at the base and tip of the TNT formed from the infected cell [100]. Importantly, HIV-1-infected MDM formed TNT that allowed gap junction communication between distant cells. Blocking these gap junctions resulted in inhibition of TNT formation and decreased HIV-1 spread in culture [100], supporting the important roles of both TNT and the gap junctions in HIV-1 cell-to-cell transfer. Viral proteins play a critical role in modulating TNT formation. For example, the HIV-1 accessory protein Nef has been recognized as a critical inducer of HIV-1-mediated TNT, through its interaction with the ubiquitous M-sec protein, an important molecular factor in TNT and cell protrusion biology [101]. HIV-1-associated TNT were also described between T cells [96]; however, macrophages and T cells TNT display different properties: in T cells, HIV-1 uses pre-existing TNT and is unable to trigger TNT formation [96]. This appears to be due to absence of M-sec expression in T cells, whereas MDM TNT were induced by Nef interactions with M-sec [101] and with myosin-X [102]. M-sec association with protein members of the exocyst complex are part of the TNT assembly mechanism [103]. Nef was found to interact with five components of the exocyst complex 
in Jurkat T cells [104], and depletion of one of these interactions led to a reduction in the number of TNT [105]. Heterotypic TNT formation between MDM and T cells can occur, and favours viral spread among different cell types [106]. It was described that Nef alone was transported from macrophages to $\mathrm{T}$ cells via TNT, a process that resulted in a decrease of CD4 expression in recipient T cells [102], and thus limiting cell-free infection events in these cells. Taken together, these studies indicate that HIV-1, mainly through Nef-dependent interactions with host proteins, hijacks physiological nanotube structures to ensure its spread and evade detection by the immune system.

\section{Implication of Co-Infections in HIV-1 Intercellular Macrophage Interactions}

HIV-1 infection is associated with comorbidities that tend to elevate morbidity and mortality. Among these comorbidities, co-infection with Plasmodium falciparum, the etiological agent for Malaria, results in enhanced infection and accelerated progression to AIDS. A mechanism that may explain greater viral load is the increased HIV-1 infection of target cells. The treatment of immature DC with the malarial pigment hemozin was reported to drive rapid DC maturation, known to be more susceptible to HIV-1 infection than their immature counterparts [107]. Pre-exposure of DC to hemozin promoted HIV-1 transfer to $\mathrm{CD}^{+} \mathrm{T}$ cells, while protecting DC from productive infection with the virus [108]. Another pathogen that adversely impacts HIV-1 pathogenesis is co-infection with Mycobacterium tuberculosis $(\mathrm{Mtb})$, the causative agent of Tuberculosis. Co-infected patients display a rise in viral load, both in the bloodstream and at the anatomical sites of co-infection [109-111], and this phenomenon was associated with macrophage rather than $\mathrm{T}$ cell infection [112]. Amongst the mechanisms proposed to explain this phenomenon, the release of TNF $\alpha, I L-6, I L-1 \beta$ and IL-10 by Mtb-infected MDM favoured the viral replication in HIV-1 infected cells, by increasing NFKB binding to HIV-1 LTR sequences [113,114]. Recently, we reported that the Mtb-associated microenvironment induced both thin and thick TNT formation between MDM in an IL-10/STAT3-dependent manner. This increased TNT formation was largely responsible for the enhanced viral replication and dissemination in the culture, since the pharmacological inhibition of these structures reversed the infection levels to that of control cells [115]. We also identified Siglec-1, previously described as important in VCC formation [49] and in the capture and transfer of HIV-1 from infected DC and MDM to CD4 ${ }^{+}$T cells [116], to be upregulated both in MDM differentiated in an Mtb-associated microenvironment, and in lung macrophages of Mtb and Mtb-SIV co-infected macaques [117]. Interestingly, Siglec-1 was highly distributed on long and thick TNT, which correlated with the viral content of these structure (Figure 3). By silencing Siglec-1, we showed that it was required for the TNT-mediated spread of HIV-1 among MDM [117]. Interestingly, Siglec-1 is not the only relevant HIV-1 receptor whose expression is enhanced by Mtb infection. Other HIV-1 adsorption receptors upregulated by Mtb include lectins involved in HIV-1 capture [118], such as mannose receptor [119,120], and entry receptors CD4, CCR5, and CXCR4 [121]. These receptors may localize both to the plasma membrane and to TNT, thus enhancing HIV-1 capture and transfer between distantly connected cells.

\section{In vivo Evidence for HIV-1 Cell-Cell Spread in Macrophage Infection and Dissemination}

Despite the description of several mechanisms of cell-to-cell transfer allowing HIV-1 spread, all of them have been described using in vitro systems. Yet it is likely that some of them also occur in vivo. Some evidence indicates that the formation of VS could occur in vivo, and possibly result in target cell infection through one or more of the mechanisms described above. Using intravital microscopy of HIV-1-infected humanized mouse lymph nodes, the group of Mempel found that about $10 \%$ to $20 \%$ of infected $\mathrm{T}$ cells presented with elongated and thin membrane protrusion of sometimes more than $100 \mu \mathrm{m}$ in length, suggesting the formation of TNT-like structures in vivo [122]. These elongated structures appear to represent multinucleate syncytia arising from Env-mediated interactions between circulating and arrested HIV-1-infected T cells, suggesting that the first stage of viral dissemination may occur via TNT formation followed by the establishment of a VS. Additionally, productively infected $\mathrm{T}$ cells efficiently migrated to the lymph node cortex, microns away from the subcapsular 
sinus (SCS), enhancing the viral spread in the tissue [122]. The role of macrophages in this process has recently been studied in mice infected with murine leukaemia virus (MLV) or HIV-1. Upon foot-pad injection of fluorescently labelled viruses, Sewald and colleagues found that both MLV and HIV-1 accumulated in the floor of the SCS, and were associated with Siglec- $1^{+}$cells, most of which were $\mathrm{CD}_{11} \mathrm{~b}^{+}$macrophages [35]. Interestingly, the inhibition or knock-out of Siglec-1 abolished the viral uptake in the peripheral lymph node, testifying to the importance of macrophages in the early phase of virus uptake and spread [35]. Indeed, the authors found that MLV-GFP viruses were selectively transferred from Siglec $-1^{+}$macrophages to a subset of B cells in the lymph node after formation of synaptic contacts, indicating that macrophages not only captured the virus and stored it in VCC, but also transferred it to target cells through VS that recruited the VCC to the contact zone [35]. Moreover, the VS were characterized, and cell protrusion containing viral particles, along with intracellular vesicles and mitochondria, were observed, indicating the formation of TNT between infected and uninfected cells in the tissue.
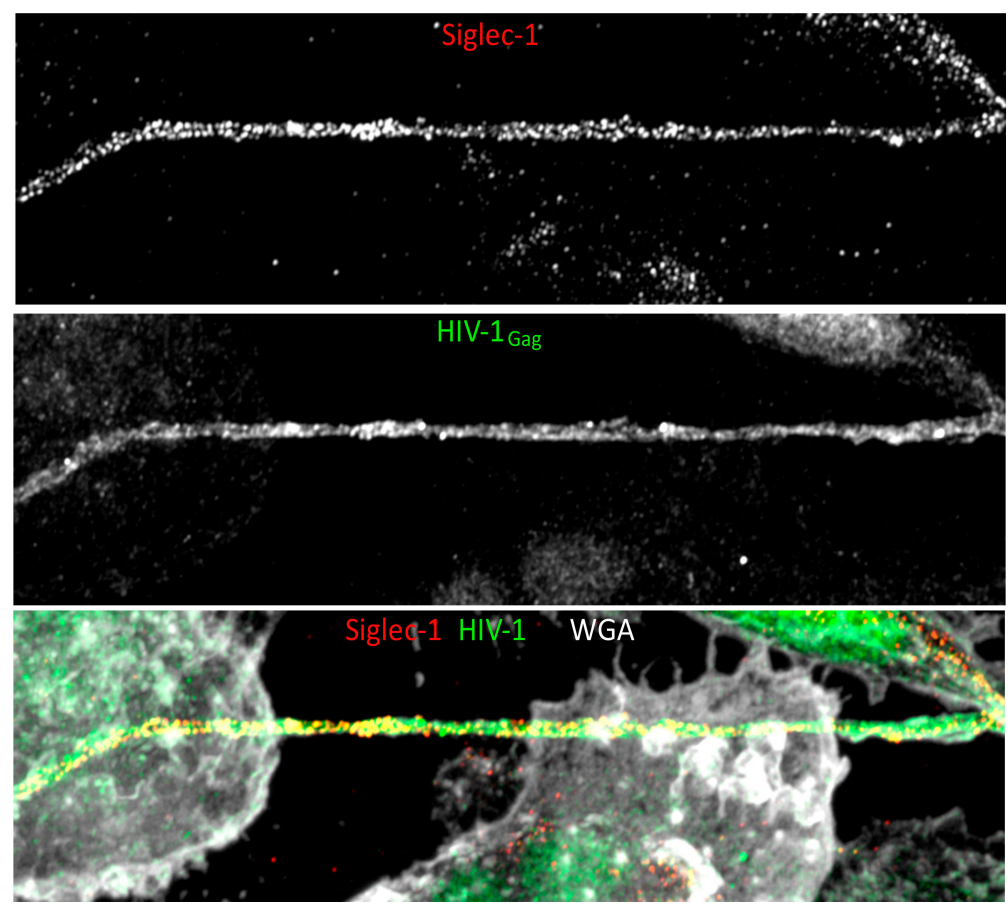

Figure 3. HIV-1 spreads between macrophages through Siglec- $1^{+}$tunneling nanotubes (TNT). Primary human monocytes were differentiated for 3 days with supernatant from Mycobacterium tuberculosisinfected MDM, and then infected with $\mathrm{HIV}-1_{\mathrm{NLAD}}-\mathrm{VSVg}$. Representative immunofluorescence labeling showing HIV $^{+}$-Siglec- $1^{+}$thick TNT (taken from [117] and used under CCBY 4.0). Staining shows extracellular Siglec-1 (top) intracellular HIV-1 ${ }_{\text {Gag }}$ (middle), and cell plasma membrane stained with Wheat Germ Agglutinin (WGA, grey) with all 3 colors merged in the lower image. Scale bar: $10 \mu \mathrm{m}$.

Non-human primate (NHP) studies have provided further evidence supporting the mechanism by which macrophages become infected through phagocytosis of, or fusion with, infected T cells. Indeed, SIV DNA has been detected in both $\mathrm{CD}^{+} \mathrm{T}$ cells and myeloid cells isolated from mucosal and lymphoid tissues in infected Asian macaques [123]. In SIV-DNA ${ }^{+}$myeloid cells, present in lymphoid tissues where CD4 ${ }^{+} \mathrm{T}$ cells persist, rearranged TCR $-\gamma \delta$ DNA was also found, indicating that these cells probably acquired viral material through infected T cell phagocytosis or fusion [123]. Furthermore, SIV-DNA-containing tissue macrophages contained replication competent viruses, similar to those found in $\mathrm{CD}^{+}{ }^{+} \mathrm{T}$ cells in untreated animals, whereas SIV DNA levels were decreased and no replication-competent virus could be detected in tissue macrophages from ART-treated animals [124]. These results were further supported by the detection of TCR- $\gamma \delta$ DNA in alveolar macrophages isolated from eight out of nine HIV-infected patients under ART for 3 years, indicating that T cell phagocytosis 
may occur in HIV patients, and could therefore participate in viral dissemination [124]. In another study, the histological section of the human lymph node and tonsils isolated from HIV-infected patients were used to determine the cell types infected in vivo. Infected $\mathrm{CD} 4^{+} \mathrm{T}$ cells were mainly located in the germinal centre and paracortex of the tissue, while the infected macrophages were in close proximity to the lumen of paracortical blood vessels. In this area, macrophages not only contained p24-positive material, but also infected T cells, along with p24-positive debris within phagosomes, supporting the hypothesis that in secondary lymphoid organs, macrophages can become infected by the phagocytosis of infected T cells [125].

\section{Discussion}

The disseminated, ubiquitous tissue location and ability of macrophages to be infected by HIV-1 and then pass the virus to other cell types makes them a cellular "infectious hub" that may remain infected for extended periods and seed virus to other macrophages and to $T$ cells via diverse mechanisms (Figure 4). The mechanisms by which HIV-1 infects macrophages and is then transmitted onwards to other cell types in vivo is unclear, but none of the proposed mechanisms (phagocytosis, fusion, nanotubes) is mutually exclusive, and so these may function in parallel. A limitation of tissue culture models of macrophage cell-cell infection is that they almost all use MDM, whereas, in vivo, tissue-resident macrophages may be derived from early embryogenesis or blood monocyte infiltration and differentiation. Extracting macrophages from tissues is complex and will alter their phenotype, as this is critically-dependent on the local cell and cytokine environment [126-128]. An alternative approach that is gaining traction is the differentiation of macrophages from induced pluripotent stem cells in a selective cytokine environment, a process that may allow more physiologically-relevant cell phenotypes to be probed in HIV-1 cell-cell infection systems [129]. Similarly, almost all in vitro analyses have used plastic as the solid phase for macrophage differentiation, coculture with other immune cells and viral cell-cell infection studies. However, macrophages exist in a 3-dimensional tissue matrix that can be better mimicked using semi-solid matrices, and macrophage behavior including migration is best explored in this setting $[130,131]$. This, together with ever more sophisticated intravital microscopic analyses [132], will lead to a more coherent and integrated understanding of how HIV-1 moves between myeloid and lymphoid cell targets and the implications of this for prophylactic, therapeutic and cure strategies.
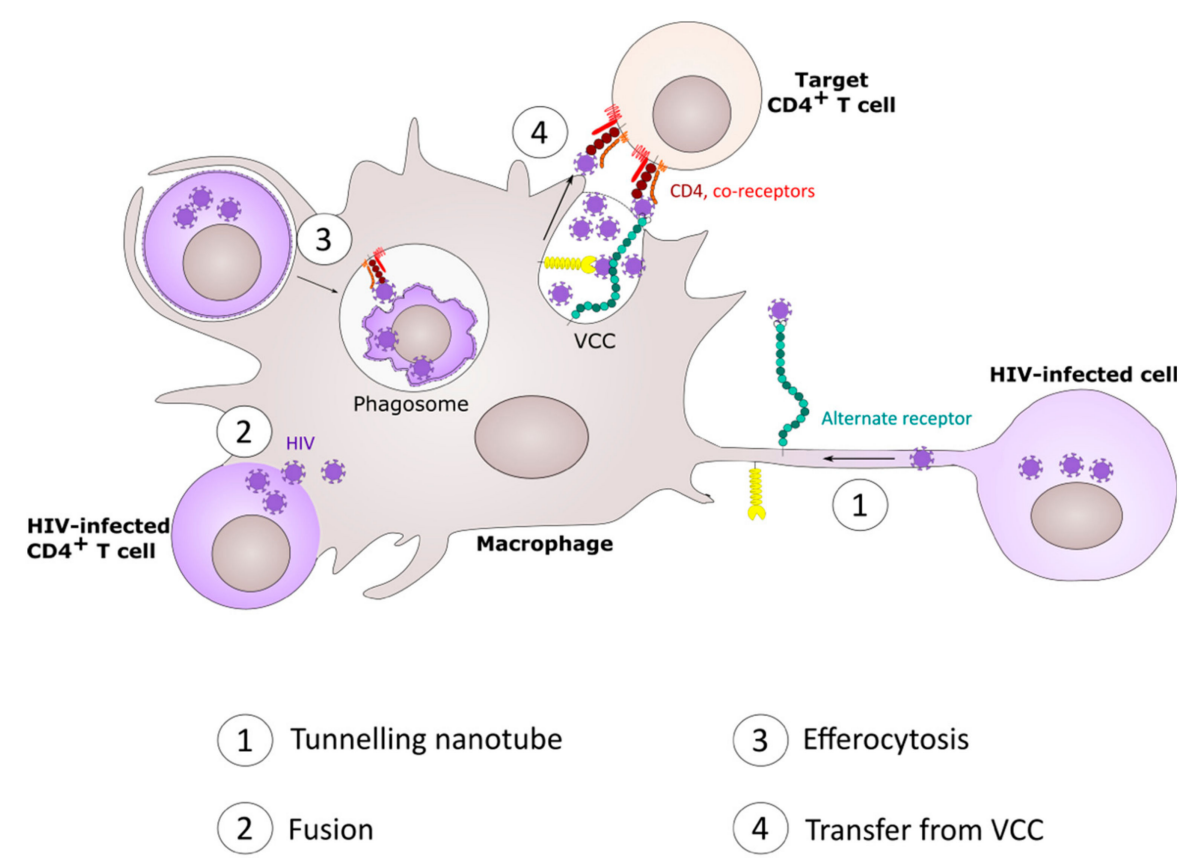

Figure 4. Cont. 


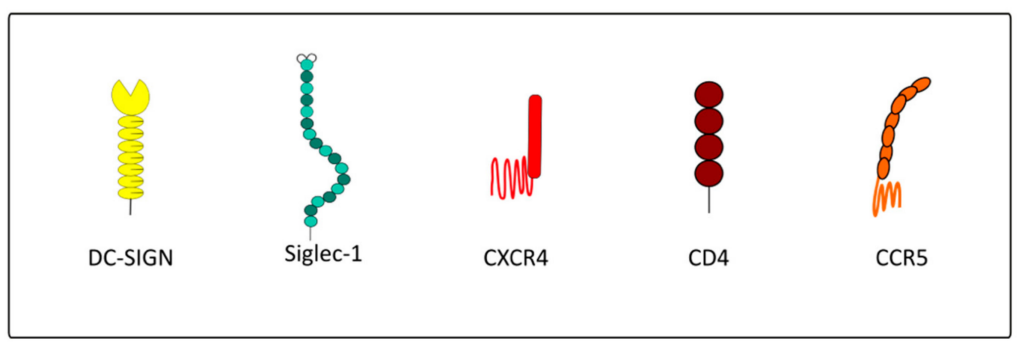

Figure 4. Model for role of the macrophage in cell-cell HIV-1 dissemination. Macrophages can become infected through different mechanisms, and participate in HIV-1 dissemination within the host. (1) HIV-infected cells form intercellular bridges-TNT—-structures hijacked by the virus to spread from one cell to another, trafficking on the inside or outside of the structure, possibly by selective use of attachment receptors (e.g., Siglec-1, DC-SIGN). (2) Macrophages fuse with acutely infected $\mathrm{CD}^{+} \mathrm{T}$ cells, leading to a viable, infected heterokaryon. (3) As professional phagocytes, macrophages recognize infected and dying $\mathrm{CD}^{+} \mathrm{T}$ cells. Release of viral particles from the $\mathrm{T}$ cell during capture and phagocytosis allows high multiplicity macrophage infection. (4) In infected macrophages, the virus buds into a specialized virus-containing compartment (VCC). Upon encounter with $\mathrm{CD} 4^{+}$target $\mathrm{T}$ cells, VCC containing either free virions or attachment receptor-bound viral particles release virions that infect the target cell.

Funding: This research received external funding from the Medical Research Council, UK

Conflicts of Interest: The authors declare no conflict of interest.

\section{References}

1. Ginhoux, F.; Guilliams, M. Tissue-Resident Macrophage Ontogeny and Homeostasis. Immunity 2016, 44, 439-449. [CrossRef]

2. Sarantis, H.; Grinstein, S. Subversion of phagocytosis for pathogen survival. Cell Host Microbe 2012, 12, 419-431. [CrossRef]

3. Weiss, G.; Schaible, U.E. Macrophage defense mechanisms against intracellular bacteria. Immunol. Rev. 2015, 264, 182-203. [CrossRef]

4. Tan, J.; Sattentau, Q.J. The HIV-1-containing macrophage compartment: A perfect cellular niche? Trends Microbiol. 2013, 21, 405-412. [CrossRef]

5. Mitchell, G.; Chen, C.; Portnoy, D.A. Strategies Used by Bacteria to Grow in Macrophages. Microbiol. Spectr. 2016, 4. [CrossRef]

6. Chow, S.H.; Deo, P.; Naderer, T. Macrophage cell death in microbial infections. Cell. Microbiol. 2016, 18, 466-474. [CrossRef]

7. Price, J.V.; Vance, R.E. The macrophage paradox. Immunity 2014, 41, 685-693. [CrossRef]

8. Ren, Y.; Khan, F.A.; Pandupuspitasari, N.S.; Zhang, S. Immune Evasion Strategies of Pathogens in Macrophages: The Potential for Limiting Pathogen Transmission. Curr. Issues Mol. Biol. 2017, 21, $21-40$.

9. Chen, B. Molecular Mechanism of HIV-1 Entry. Trends Microbiol. 2019, 27, 878-891. [CrossRef]

10. Li, G.H.; Henderson, L.; Nath, A. Astrocytes as an HIV Reservoir: Mechanism of HIV Infection. Curr. HIV Res. 2016, 14, 373-381. [CrossRef]

11. Li, G.H.; Maric, D.; Major, E.O.; Nath, A. Productive HIV infection in astrocytes can be established via a non-classical mechanism. AIDS 2020. [CrossRef]

12. Joseph, S.B.; Swanstrom, R. The evolution of HIV-1 entry phenotypes as a guide to changing target cells. J. Leukoc. Biol. 2018, 103, 421-431. [CrossRef] [PubMed]

13. Duncan, C.J.; Sattentau, Q.J. Viral determinants of HIV-1 macrophage tropism. Viruses 2011, 3, $2255-2279$. [CrossRef]

14. Bertram, K.M.; Tong, O.; Royle, C.; Turville, S.G.; Nasr, N.; Cunningham, A.L.; Harman, A.N. Manipulation of Mononuclear Phagocytes by HIV: Implications for Early Transmission Events. Front. Immunol. 2019, 10, 2263. [CrossRef] 
15. Salazar-Gonzalez, J.F.; Salazar, M.G.; Keele, B.F.; Learn, G.H.; Giorgi, E.E.; Li, H.; Decker, J.M.; Wang, S.; Baalwa, J.; Kraus, M.H.; et al. Genetic identity, biological phenotype, and evolutionary pathways of transmitted/founder viruses in acute and early HIV-1 infection. J. Exp. Med. 2009, 206, 1273-1289. [CrossRef]

16. Ochsenbauer, C.; Edmonds, T.G.; Ding, H.; Keele, B.F.; Decker, J.; Salazar, M.G.; Salazar-Gonzalez, J.F.; Shattock, R.; Haynes, B.F.; Shaw, G.M.; et al. Generation of transmitted/founder HIV-1 infectious molecular clones and characterization of their replication capacity in CD4 T lymphocytes and monocyte-derived macrophages. J. Virol. 2012, 86, 2715-2728. [CrossRef]

17. Sattentau, Q. Avoiding the void: Cell-to-cell spread of human viruses. Nat. Rev. Microbiol. 2008, 6, 815-826. [CrossRef]

18. Martin, N.; Welsch, S.; Jolly, C.; Briggs, J.A.; Vaux, D.; Sattentau, Q.J. Virological synapse-mediated spread of human immunodeficiency virus type 1 between T cells is sensitive to entry inhibition. J. Virol. 2010, 84, 3516-3527. [CrossRef]

19. Sourisseau, M.; Sol-Foulon, N.; Porrot, F.; Blanchet, F.; Schwartz, O. Inefficient human immunodeficiency virus replication in mobile lymphocytes. J. Virol. 2007, 81, 1000-1012. [CrossRef]

20. Jolly, C.; Welsch, S.; Michor, S.; Sattentau, Q.J. The regulated secretory pathway in CD4(+) T cells contributes to human immunodeficiency virus type-1 cell-to-cell spread at the virological synapse. PLoS Pathog. 2011, 7, e1002226. [CrossRef]

21. Jolly, C.; Kashefi, K.; Hollinshead, M.; Sattentau, Q.J. HIV-1 cell to cell transfer across an Env-induced, actin-dependent synapse. J. Exp. Med. 2004, 199, 283-293. [CrossRef]

22. Jolly, C.; Booth, N.J.; Neil, S.J. Cell-cell spread of human immunodeficiency virus type 1 overcomes tetherin/BST-2-mediated restriction in T cells. J. Virol. 2010, 84, 12185-12199. [CrossRef]

23. Zhong, P.; Agosto, L.M.; Ilinskaya, A.; Dorjbal, B.; Truong, R.; Derse, D.; Uchil, P.D.; Heidecker, G.; Mothes, W. Cell-to-cell transmission can overcome multiple donor and target cell barriers imposed on cell-free HIV. PLoS ONE 2013, 8, e53138. [CrossRef]

24. Dufloo, J.; Bruel, T.; Schwartz, O. HIV-1 cell-to-cell transmission and broadly neutralizing antibodies. Retrovirology 2018, 15, 51. [CrossRef]

25. Schiffner, T.; Sattentau, Q.J.; Duncan, C.J. Cell-to-cell spread of HIV-1 and evasion of neutralizing antibodies. Vaccine 2013, 31, 5789-5797. [CrossRef]

26. Duncan, C.J.; Russell, R.A.; Sattentau, Q.J. High multiplicity HIV-1 cell-to-cell transmission from macrophages to CD4+ T cells limits antiretroviral efficacy. AIDS 2013, 27, 2201-2206. [CrossRef]

27. Sigal, A.; Kim, J.T.; Balazs, A.B.; Dekel, E.; Mayo, A.; Milo, R.; Baltimore, D. Cell-to-cell spread of HIV permits ongoing replication despite antiretroviral therapy. Nature 2011, 477, 95-98. [CrossRef]

28. Agosto, L.M.; Zhong, P.; Munro, J.; Mothes, W. Highly active antiretroviral therapies are effective against HIV-1 cell-to-cell transmission. PLoS Pathog. 2014, 10, e1003982. [CrossRef]

29. Jolly, C.; Sattentau, Q.J. Retroviral spread by induction of virological synapses. Traffic 2004, 5, 643-650. [CrossRef]

30. Alvarez, R.A.; Barria, M.I.; Chen, B.K. Unique features of HIV-1 spread through T cell virological synapses. PLoS Pathog. 2014, 10, e1004513. [CrossRef]

31. Sabatos, C.A.; Doh, J.; Chakravarti, S.; Friedman, R.S.; Pandurangi, P.G.; Tooley, A.J.; Krummel, M.F. A synaptic basis for paracrine interleukin-2 signaling during homotypic T cell interaction. Immunity 2008, 29, 238-248. [CrossRef]

32. Pope, M.; Betjes, M.G.; Romani, N.; Hirmand, H.; Cameron, P.U.; Hoffman, L.; Gezelter, S.; Schuler, G.; Steinman, R.M. Conjugates of dendritic cells and memory T lymphocytes from skin facilitate productive infection with HIV-1. Cell 1994, 78, 389-398. [CrossRef]

33. Izquierdo-Useros, N.; Lorizate, M.; McLaren, P.J.; Telenti, A.; Krausslich, H.G.; Martinez-Picado, J. HIV-1 capture and transmission by dendritic cells: The role of viral glycolipids and the cellular receptor Siglec-1. PLoS Pathog. 2014, 10, e1004146. [CrossRef] [PubMed]

34. McDonald, D. Dendritic Cells and HIV-1 Trans-Infection. Viruses 2010, 2, 1704-1717. [CrossRef] [PubMed]

35. Sewald, X.; Ladinsky, M.S.; Uchil, P.D.; Beloor, J.; Pi, R.; Herrmann, C.; Motamedi, N.; Murooka, T.T.; Brehm, M.A.; Greiner, D.L.; et al. Retroviruses use CD169-mediated trans-infection of permissive lymphocytes to establish infection. Science 2015, 350, 563-567. [CrossRef] 
36. Yu, H.J.; Reuter, M.A.; McDonald, D. HIV traffics through a specialized, surface-accessible intracellular compartment during trans-infection of T cells by mature dendritic cells. PLoS Pathog. 2008, 4, e1000134. [CrossRef]

37. Gendelman, H.E.; Baca, L.M.; Husayni, H.; Turpin, J.A.; Skillman, D.; Kalter, D.C.; Orenstein, J.M.; Hoover, D.L.; Meltzer, M.S. Macrophage-HIV interaction: Viral isolation and target cell tropism. AIDS 1990, 4, 221-228. [CrossRef]

38. Orenstein, J.M.; Meltzer, M.S.; Phipps, T.; Gendelman, H.E. Cytoplasmic assembly and accumulation of human immunodeficiency virus types 1 and 2 in recombinant human colony-stimulating factor-1-treated human monocytes: An ultrastructural study. J. Virol. 1988, 62, 2578-2586. [CrossRef]

39. Deneka, M.; Pelchen-Matthews, A.; Byland, R.; Ruiz-Mateos, E.; Marsh, M. In macrophages, HIV-1 assembles into an intracellular plasma membrane domain containing the tetraspanins CD81, CD9, and CD53. J. Cell. Biol. 2007, 177, 329-341. [CrossRef]

40. Jouve, M.; Sol-Foulon, N.; Watson, S.; Schwartz, O.; Benaroch, P. HIV-1 buds and accumulates in "nonacidic" endosomes of macrophages. Cell Host Microbe 2007, 2, 85-95. [CrossRef]

41. Welsch, S.; Keppler, O.T.; Habermann, A.; Allespach, I.; Krijnse-Locker, J.; Krausslich, H.G. HIV-1 buds predominantly at the plasma membrane of primary human macrophages. PLoS Pathog. 2007, 3, e36. [CrossRef] [PubMed]

42. Welsch, S.; Groot, F.; Krausslich, H.G.; Keppler, O.T.; Sattentau, Q.J. Architecture and regulation of the HIV-1 assembly and holding compartment in macrophages. J. Virol. 2011, 85, 7922-7927. [CrossRef] [PubMed]

43. Sharova, N.; Swingler, C.; Sharkey, M.; Stevenson, M. Macrophages archive HIV-1 virions for dissemination in trans. EMBO J. 2005, 24, 2481-2489. [CrossRef] [PubMed]

44. Pelchen-Matthews, A.; Giese, S.; Mlcochova, P.; Turner, J.; Marsh, M. beta2 integrin adhesion complexes maintain the integrity of HIV-1 assembly compartments in primary macrophages. Traffic 2012, 13, 273-291. [CrossRef]

45. Mlcochova, P.; Pelchen-Matthews, A.; Marsh, M. Organization and regulation of intracellular plasma membrane-connected HIV-1 assembly compartments in macrophages. BMC Biol. 2013, 11, 89. [CrossRef]

46. Bennett, A.E.; Narayan, K.; Shi, D.; Hartnell, L.M.; Gousset, K.; He, H.; Lowekamp, B.C.; Yoo, T.S.; Bliss, D.; Freed, E.O.; et al. Ion-abrasion scanning electron microscopy reveals surface-connected tubular conduits in HIV-infected macrophages. PLoS Pathog. 2009, 5, e1000591. [CrossRef]

47. Gaudin, R.; Berre, S.; Cunha de Alencar, B.; Decalf, J.; Schindler, M.; Gobert, F.X.; Jouve, M.; Benaroch, P. Dynamics of HIV-containing compartments in macrophages reveal sequestration of virions and transient surface connections. PLoS ONE 2013, 8, e69450. [CrossRef]

48. Berre, S.; Gaudin, R.; Cunha de Alencar, B.; Desdouits, M.; Chabaud, M.; Naffakh, N.; Rabaza-Gairi, M.; Gobert, F.X.; Jouve, M.; Benaroch, P. CD36-specific antibodies block release of HIV-1 from infected primary macrophages and its transmission to T cells. J. Exp. Med. 2013, 210, 2523-2538. [CrossRef]

49. Hammonds, J.E.; Beeman, N.; Ding, L.; Takushi, S.; Francis, A.C.; Wang, J.J.; Melikyan, G.B.; Spearman, P. Siglec-1 initiates formation of the virus-containing compartment and enhances macrophage-to-T cell transmission of HIV-1. PLoS Pathog. 2017, 13, e1006181. [CrossRef]

50. Gousset, K.; Ablan, S.D.; Coren, L.V.; Ono, A.; Soheilian, F.; Nagashima, K.; Ott, D.E.; Freed, E.O. Real-time visualization of HIV-1 GAG trafficking in infected macrophages. PLoS Pathog. 2008, 4, e1000015. [CrossRef]

51. Gaudin, R.; de Alencar, B.C.; Jouve, M.; Berre, S.; Le Bouder, E.; Schindler, M.; Varthaman, A.; Gobert, F.X.; Benaroch, P. Critical role for the kinesin KIF3A in the HIV life cycle in primary human macrophages. J. Cell. Biol. 2012, 199, 467-479. [CrossRef] [PubMed]

52. Ganor, Y.; Real, F.; Sennepin, A.; Dutertre, C.A.; Prevedel, L.; Xu, L.; Tudor, D.; Charmeteau, B.; Couedel-Courteille, A.; Marion, S.; et al. HIV-1 reservoirs in urethral macrophages of patients under suppressive antiretroviral therapy. Nat. Microbiol. 2019, 4, 633-644. [CrossRef] [PubMed]

53. Carr, J.M.; Hocking, H.; Li, P.; Burrell, C.J. Rapid and efficient cell-to-cell transmission of human immunodeficiency virus infection from monocyte-derived macrophages to peripheral blood lymphocytes. Virology 1999, 265, 319-329. [CrossRef] [PubMed]

54. Swingler, S.; Brichacek, B.; Jacque, J.M.; Ulich, C.; Zhou, J.; Stevenson, M. HIV-1 Nef intersects the macrophage CD40L signalling pathway to promote resting-cell infection. Nature 2003, 424, 213-219. [CrossRef] [PubMed]

55. Groot, F.; Welsch, S.; Sattentau, Q.J. Efficient HIV-1 transmission from macrophages to T cells across transient virological synapses. Blood 2008, 111, 4660-4663. [CrossRef] [PubMed] 
56. Duncan, C.J.; Williams, J.P.; Schiffner, T.; Gartner, K.; Ochsenbauer, C.; Kappes, J.; Russell, R.A.; Frater, J.; Sattentau, Q.J. High-multiplicity HIV-1 infection and neutralizing antibody evasion mediated by the macrophage-T cell virological synapse. J. Virol. 2014, 88, 2025-2034. [CrossRef]

57. Herbein, G.; Gras, G.; Khan, K.A.; Abbas, W. Macrophage signaling in HIV-1 infection. Retrovirology 2010, 7, 34. [CrossRef]

58. Kulpa, D.A.; Brehm, J.H.; Fromentin, R.; Cooper, A.; Cooper, C.; Ahlers, J.; Chomont, N.; Sekaly, R.P. The immunological synapse: The gateway to the HIV reservoir. Immunol. Rev. 2013, 254, 305-325. [CrossRef]

59. Evans, V.A.; Kumar, N.; Filali, A.; Procopio, F.A.; Yegorov, O.; Goulet, J.P.; Saleh, S.; Haddad, E.K.; da Fonseca Pereira, C.; Ellenberg, P.C.; et al. Myeloid dendritic cells induce HIV-1 latency in non-proliferating CD4+ T cells. PLoS Pathog. 2013, 9, e1003799. [CrossRef]

60. Kumar, N.A.; Cheong, K.; Powell, D.R.; da Fonseca Pereira, C.; Anderson, J.; Evans, V.A.; Lewin, S.R.; Cameron, P.U. The role of antigen presenting cells in the induction of HIV-1 latency in resting CD4(+) T-cells. Retrovirology 2015, 12, 76. [CrossRef]

61. Kumar, N.A.; van der Sluis, R.M.; Mota, T.; Pascoe, R.; Evans, V.A.; Lewin, S.R.; Cameron, P.U. Myeloid Dendritic Cells Induce HIV Latency in Proliferating CD4(+) T Cells. J. Immunol. 2018, 201, 1468-1477. [CrossRef] [PubMed]

62. Cassol, E.; Cassetta, L.; Alfano, M.; Poli, G. Macrophage polarization and HIV-1 infection. J. Leukoc. Biol. 2010, 87, 599-608. [CrossRef] [PubMed]

63. Saidi, H.; Carbonneil, C.; Magri, G.; Eslahpazir, J.; Sekaly, R.P.; Belec, L. Differential modulation of CCR5-tropic human immunodeficiency virus-1 transfer from macrophages towards $\mathrm{T}$ cells under interleukin4/interleukin-13 microenvironment. Hum. Immunol. 2010, 71, 1-13. [CrossRef] [PubMed]

64. Cassol, E.; Cassetta, L.; Rizzi, C.; Gabuzda, D.; Alfano, M.; Poli, G. Dendritic cell-specific intercellular adhesion molecule-3 grabbing nonintegrin mediates HIV-1 infection of and transmission by M2a-polarized macrophages in vitro. AIDS 2013, 27, 707-716. [CrossRef]

65. Baxter, A.E.; Russell, R.A.; Duncan, C.J.; Moore, M.D.; Willberg, C.B.; Pablos, J.L.; Finzi, A.; Kaufmann, D.E.; Ochsenbauer, C.; Kappes, J.C.; et al. Macrophage infection via selective capture of HIV-1-infected CD4+ T cells. Cell Host Microbe 2014, 16, 711-721. [CrossRef]

66. Czuczman, M.A.; Fattouh, R.; van Rijn, J.M.; Canadien, V.; Osborne, S.; Muise, A.M.; Kuchroo, V.K.; Higgins, D.E.; Brumell, J.H. Listeria monocytogenes exploits efferocytosis to promote cell-to-cell spread. Nature 2014, 509, 230-234. [CrossRef]

67. Davis, J.M.; Ramakrishnan, L. The role of the granuloma in expansion and dissemination of early tuberculous infection. Cell 2009, 136, 37-49. [CrossRef]

68. Ritter, U.; Frischknecht, F.; van Zandbergen, G. Are neutrophils important host cells for Leishmania parasites? Trends Parasitol. 2009, 25, 505-510. [CrossRef]

69. Karaji, N.; Sattentau, Q.J. Efferocytosis of Pathogen-Infected Cells. Front. Immunol. 2017, 8, 1863. [CrossRef]

70. Russell, R.A.; Chojnacki, J.; Jones, D.M.; Johnson, E.; Do, T.; Eggeling, C.; Padilla-Parra, S.; Sattentau, Q.J. Astrocytes Resist HIV-1 Fusion but Engulf Infected Macrophage Material. Cell Rep. 2017, 18, 1473-1483. [CrossRef]

71. Ma, M.; Geiger, J.D.; Nath, A. Characterization of a novel binding site for the human immunodeficiency virus type 1 envelope protein gp120 on human fetal astrocytes. J. Virol. 1994, 68, 6824-6828. [CrossRef] [PubMed]

72. Sabri, F.; Tresoldi, E.; Di Stefano, M.; Polo, S.; Monaco, M.C.; Verani, A.; Fiore, J.R.; Lusso, P.; Major, E.; Chiodi, F.; et al. Nonproductive human immunodeficiency virus type 1 infection of human fetal astrocytes: Independence from CD4 and major chemokine receptors. Virology 1999, 264, 370-384. [CrossRef] [PubMed]

73. Willey, S.J.; Reeves, J.D.; Hudson, R.; Miyake, K.; Dejucq, N.; Schols, D.; De Clercq, E.; Bell, J.; McKnight, A.; Clapham, P.R. Identification of a subset of human immunodeficiency virus type 1 (HIV-1), HIV-2, and simian immunodeficiency virus strains able to exploit an alternative coreceptor on untransformed human brain and lymphoid cells. J. Virol. 2003, 77, 6138-6152. [CrossRef] [PubMed]

74. Canki, M.; Thai, J.N.; Chao, W.; Ghorpade, A.; Potash, M.J.; Volsky, D.J. Highly productive infection with pseudotyped human immunodeficiency virus type 1 (HIV-1) indicates no intracellular restrictions to HIV-1 replication in primary human astrocytes. J. Virol. 2001, 75, 7925-7933. [CrossRef]

75. Gray, L.R.; Tachedjian, G.; Ellett, A.M.; Roche, M.J.; Cheng, W.J.; Guillemin, G.J.; Brew, B.J.; Turville, S.G.; Wesselingh, S.L.; Gorry, P.R.; et al. The NRTIs lamivudine, stavudine and zidovudine have reduced HIV-1 inhibitory activity in astrocytes. PLoS ONE 2013, 8, e62196. [CrossRef] 
76. Chauhan, A. Enigma of HIV-1 latent infection in astrocytes: An in-vitro study using protein kinase C agonist as a latency reversing agent. Microbes Infect. 2015, 17, 651-659. [CrossRef]

77. Chang, G.H.; Barbaro, N.M.; Pieper, R.O. Phosphatidylserine-dependent phagocytosis of apoptotic glioma cells by normal human microglia, astrocytes, and glioma cells. Neuro. Oncol. 2000, 2, 174-183. [CrossRef]

78. Loov, C.; Hillered, L.; Ebendal, T.; Erlandsson, A. Engulfing astrocytes protect neurons from contact-induced apoptosis following injury. PLoS ONE 2012, 7, e33090. [CrossRef]

79. Loov, C.; Mitchell, C.H.; Simonsson, M.; Erlandsson, A. Slow degradation in phagocytic astrocytes can be enhanced by lysosomal acidification. Glia 2015, 63, 1997-2009. [CrossRef]

80. Gray, L.R.; Turville, S.G.; Hitchen, T.L.; Cheng, W.J.; Ellett, A.M.; Salimi, H.; Roche, M.J.; Wesselingh, S.L.; Gorry, P.R.; Churchill, M.J. HIV-1 entry and trans-infection of astrocytes involves CD81 vesicles. PLoS ONE 2014, 9, e90620. [CrossRef]

81. Churchill, M.J.; Gorry, P.R.; Cowley, D.; Lal, L.; Sonza, S.; Purcell, D.F.; Thompson, K.A.; Gabuzda, D.; McArthur, J.C.; Pardo, C.A.; et al. Use of laser capture microdissection to detect integrated HIV-1 DNA in macrophages and astrocytes from autopsy brain tissues. J. Neurovirol. 2006, 12, 146-152. [CrossRef] [PubMed]

82. Churchill, M.J.; Wesselingh, S.L.; Cowley, D.; Pardo, C.A.; McArthur, J.C.; Brew, B.J.; Gorry, P.R. Extensive astrocyte infection is prominent in human immunodeficiency virus-associated dementia. Ann. Neurol. 2009, 66, 253-258. [CrossRef] [PubMed]

83. Josefsson, L.; von Stockenstrom, S.; Faria, N.R.; Sinclair, E.; Bacchetti, P.; Killian, M.; Epling, L.; Tan, A.; Ho, T.; Lemey, P.; et al. The HIV-1 reservoir in eight patients on long-term suppressive antiretroviral therapy is stable with few genetic changes over time. Proc. Natl. Acad. Sci USA 2013, 110, E4987-E4996. [CrossRef] [PubMed]

84. Sattentau, Q.J.; Stevenson, M. Macrophages and HIV-1: An Unhealthy Constellation. Cell Host Microbe 2016, 19, 304-310. [CrossRef]

85. Ruggiero, E.; Bona, R.; Muratori, C.; Federico, M. Virological consequences of early events following cell-cell contact between human immunodeficiency virus type 1-infected and uninfected CD4+ cells. J. Virol. 2008, 82, 7773-7789. [CrossRef]

86. Frankel, S.S.; Wenig, B.M.; Burke, A.P.; Mannan, P.; Thompson, L.D.; Abbondanzo, S.L.; Nelson, A.M.; Pope, M.; Steinman, R.M. Replication of HIV-1 in dendritic cell-derived syncytia at the mucosal surface of the adenoid. Science 1996, 272, 115-117. [CrossRef]

87. Martinez-Mendez, D.; Rivera-Toledo, E.; Ortega, E.; Licona-Limon, I.; Huerta, L. Monocyte-lymphocyte fusion induced by the HIV-1 envelope generates functional heterokaryons with an activated monocyte-like phenotype. Exp. Cell. Res. 2017, 352, 9-19. [CrossRef]

88. Bracq, L.; Xie, M.; Lambele, M.; Vu, L.T.; Matz, J.; Schmitt, A.; Delon, J.; Zhou, P.; Randriamampita, C.; Bouchet, J.; et al. T Cell-Macrophage Fusion Triggers Multinucleated Giant Cell Formation for HIV-1 Spreading. J. Virol. 2017, 91. [CrossRef]

89. Ono, A.; Freed, E.O. Cell-type-dependent targeting of human immunodeficiency virus type 1 assembly to the plasma membrane and the multivesicular body. J. Virol. 2004, 78, 1552-1563. [CrossRef]

90. Xie, M.; Leroy, H.; Mascarau, R.; Woottum, M.; Dupont, M.; Ciccone, C.; Schmitt, A.; Raynaud-Messina, B.; Verollet, C.; Bouchet, J.; et al. Cell-to-Cell Spreading of HIV-1 in Myeloid Target Cells Escapes SAMHD1 Restriction. mBio 2019, 10. [CrossRef]

91. Bell, J.E. The neuropathology of adult HIV infection. Rev. Neurol. (Paris) 1998, 154, 816-829. [PubMed]

92. Mittal, R.; Karhu, E.; Wang, J.S.; Delgado, S.; Zukerman, R.; Mittal, J.; Jhaveri, V.M. Cell communication by tunneling nanotubes: Implications in disease and therapeutic applications. J. Cell. Physiol. 2019, 234, 1130-1146. [CrossRef] [PubMed]

93. Dupont, M.; Souriant, S.; Lugo-Villarino, G.; Maridonneau-Parini, I.; Verollet, C. Tunneling Nanotubes: Intimate Communication between Myeloid Cells. Front. Immunol. 2018, 9, 43. [CrossRef] [PubMed]

94. Sisakhtnezhad, S.; Khosravi, L. Emerging physiological and pathological implications of tunneling nanotubes formation between cells. Eur. J. Cell. Biol. 2015, 94, 429-443. [CrossRef] [PubMed]

95. McCoy-Simandle, K.; Hanna, S.J.; Cox, D. Exosomes and nanotubes: Control of immune cell communication. Int. J. Biochem. Cell. Biol. 2016, 71, 44-54. [CrossRef] [PubMed]

96. Sowinski, S.; Jolly, C.; Berninghausen, O.; Purbhoo, M.A.; Chauveau, A.; Kohler, K.; Oddos, S.; Eissmann, P.; Brodsky, F.M.; Hopkins, C.; et al. Membrane nanotubes physically connect $\mathrm{T}$ cells over long distances presenting a novel route for HIV-1 transmission. Nat. Cell. Biol. 2008, 10, 211-219. [CrossRef] 
97. Eugenin, E.A.; Gaskill, P.J.; Berman, J.W. Tunneling nanotubes (TNT) are induced by HIV-infection of macrophages: A potential mechanism for intercellular HIV trafficking. Cell. Immunol. 2009, 254, 142-148. [CrossRef]

98. Kadiu, I.; Gendelman, H.E. Human immunodeficiency virus type 1 endocytic trafficking through macrophage bridging conduits facilitates spread of infection. J. Neuroimmune. Pharmacol. 2011, 6, 658-675. [CrossRef]

99. Kadiu, I.; Gendelman, H.E. Macrophage bridging conduit trafficking of HIV-1 through the endoplasmic reticulum and Golgi network. J. Proteome Res. 2011, 10, 3225-3238. [CrossRef]

100. Okafo, G.; Prevedel, L.; Eugenin, E. Tunneling nanotubes (TNT) mediate long-range gap junctional communication: Implications for HIV cell to cell spread. Sci. Rep. 2017, 7, 16660. [CrossRef]

101. Hashimoto, M.; Bhuyan, F.; Hiyoshi, M.; Noyori, O.; Nasser, H.; Miyazaki, M.; Saito, T.; Kondoh, Y.; Osada, H.; Kimura, S.; et al. Potential Role of the Formation of Tunneling Nanotubes in HIV-1 Spread in Macrophages. J. Immunol. 2016. [CrossRef] [PubMed]

102. Uhl, J.; Gujarathi, S.; Waheed, A.A.; Gordon, A.; Freed, E.O.; Gousset, K. Myosin-X is essential to the intercellular spread of HIV-1 Nef through tunneling nanotubes. J. Cell. Commun. Signal. 2019, 13, $209-224$. [CrossRef] [PubMed]

103. Hase, K.; Kimura, S.; Takatsu, H.; Ohmae, M.; Kawano, S.; Kitamura, H.; Ito, M.; Watarai, H.; Hazelett, C.C.; Yeaman, C.; et al. M-Sec promotes membrane nanotube formation by interacting with Ral and the exocyst complex. Nat. Cell. Biol. 2009, 11, 1427-1432. [CrossRef] [PubMed]

104. Imle, A.; Abraham, L.; Tsopoulidis, N.; Hoflack, B.; Saksela, K.; Fackler, O.T. Association with PAK2 Enables Functional Interactions of Lentiviral Nef Proteins with the Exocyst Complex. mBio 2015, 6, e01309-e01315. [CrossRef]

105. Mukerji, J.; Olivieri, K.C.; Misra, V.; Agopian, K.A.; Gabuzda, D. Proteomic analysis of HIV-1 Nef cellular binding partners reveals a role for exocyst complex proteins in mediating enhancement of intercellular nanotube formation. Retrovirology 2012, 9, 33. [CrossRef]

106. Xu, W.; Santini, P.A.; Sullivan, J.S.; He, B.; Shan, M.; Ball, S.C.; Dyer, W.B.; Ketas, T.J.; Chadburn, A.; Cohen-Gould, L.; et al. HIV-1 evades virus-specific IgG2 and IgA responses by targeting systemic and intestinal B cells via long-range intercellular conduits. Nat. Immunol. 2009, 10, 1008-1017. [CrossRef]

107. Diou, J.; Tardif, M.R.; Barat, C.; Tremblay, M.J. Malaria hemozoin modulates susceptibility of immature monocyte-derived dendritic cells to HIV-1 infection by inducing a mature-like phenotype. Cell. Microbiol. 2010, 12, 615-625. [CrossRef]

108. Diou, J.; Tardif, M.R.; Barat, C.; Tremblay, M.J. Dendritic cells derived from hemozoin-loaded monocytes display a partial maturation phenotype that promotes HIV-1 trans-infection of CD4+ T cells and virus replication. J. Immunol. 2010, 184, 2899-2907. [CrossRef]

109. Nakata, K.; Rom, W.N.; Honda, Y.; Condos, R.; Kanegasaki, S.; Cao, Y.; Weiden, M. Mycobacterium tuberculosis enhances human immunodeficiency virus-1 replication in the lung. Am. J. Respir. Crit. Care Med. 1997, 155, 996-1003. [CrossRef]

110. Goletti, D.; Weissman, D.; Jackson, R.W.; Graham, N.M.; Vlahov, D.; Klein, R.S.; Munsiff, S.S.; Ortona, L.; Cauda, R.; Fauci, A.S. Effect of Mycobacterium tuberculosis on HIV replication. Role of immune activation. J. Immunol. 1996, 157, 1271-1278.

111. Toossi, Z.; Johnson, J.L.; Kanost, R.A.; Wu, M.; Luzze, H.; Peters, P.; Okwera, A.; Joloba, M.; Mugyenyi, P.; Mugerwa, R.D.; et al. Increased replication of HIV-1 at sites of Mycobacterium tuberculosis infection: Potential mechanisms of viral activation. J. Acquir. Immune. Defic. Syndr. 2001, 28, 1-8. [CrossRef] [PubMed]

112. Lawn, S.D.; Pisell, T.L.; Hirsch, C.S.; Wu, M.; Butera, S.T.; Toossi, Z. Anatomically compartmentalized human immunodeficiency virus replication in HLA-DR+ cells and CD14+ macrophages at the site of pleural tuberculosis coinfection. J. Infect. Dis. 2001, 184, 1127-1133. [CrossRef] [PubMed]

113. Duh, E.J.; Maury, W.J.; Folks, T.M.; Fauci, A.S.; Rabson, A.B. Tumor necrosis factor alpha activates human immunodeficiency virus type 1 through induction of nuclear factor binding to the NF-kappa B sites in the long terminal repeat. Proc. Natl. Acad. Sci USA 1989, 86, 5974-5978. [CrossRef] [PubMed]

114. Hoshino, Y.; Hoshino, S.; Gold, J.A.; Raju, B.; Prabhakar, S.; Pine, R.; Rom, W.N.; Nakata, K.; Weiden, M. Mechanisms of polymorphonuclear neutrophil-mediated induction of HIV-1 replication in macrophages during pulmonary tuberculosis. J. Infect. Dis. 2007, 195, 1303-1310. [CrossRef] [PubMed] 
115. Souriant, S.; Balboa, L.; Dupont, M.; Pingris, K.; Kviatcovsky, D.; Cougoule, C.; Lastrucci, C.; Bah, A.; Gasser, R.; Poincloux, R.; et al. Tuberculosis Exacerbates HIV-1 Infection through IL-10/STAT3-Dependent Tunneling Nanotube Formation in Macrophages. Cell Rep. 2019, 26, 3586-3599.e7. [CrossRef] [PubMed]

116. Martinez-Picado, J.; McLaren, P.J.; Telenti, A.; Izquierdo-Useros, N. Retroviruses As Myeloid Cell Riders: What Natural Human Siglec-1 “Knockouts" Tell Us About Pathogenesis. Front. Immunol. 2017, 8, 1593. [CrossRef] [PubMed]

117. Dupont, M.; Souriant, S.; Balboa, L.; Vu Manh, T.P.; Pingris, K.; Rousset, S.; Cougoule, C.; Rombouts, Y.; Poincloux, R.; Ben Neji, M.; et al. Tuberculosis-associated IFN-I induces Siglec-1 on tunneling nanotubes and favors HIV-1 spread in macrophages. Elife 2020, 9. [CrossRef]

118. Ugolini, S.; Mondor, I.; Sattentau, Q.J. HIV-1 attachment: Another look. Trends Microbiol. 1999, 7, $144-149$. [CrossRef]

119. Lastrucci, C.; Benard, A.; Balboa, L.; Pingris, K.; Souriant, S.; Poincloux, R.; Al Saati, T.; Rasolofo, V.; Gonzalez-Montaner, P.; Inwentarz, S.; et al. Tuberculosis is associated with expansion of a motile, permissive and immunomodulatory CD16(+) monocyte population via the IL-10/STAT3 axis. Cell Res. 2015, 25, 1333-1351. [CrossRef]

120. Lai, J.; Bernhard, O.K.; Turville, S.G.; Harman, A.N.; Wilkinson, J.; Cunningham, A.L. Oligomerization of the macrophage mannose receptor enhances gp120-mediated binding of HIV-1. J. Biol. Chem. 2009, 284, 11027-11038. [CrossRef]

121. Rosas-Taraco, A.G.; Arce-Mendoza, A.Y.; Caballero-Olin, G.; Salinas-Carmona, M.C. Mycobacterium tuberculosis upregulates coreceptors CCR5 and CXCR4 while HIV modulates CD14 favoring concurrent infection. AIDS Res. Hum. Retrovir. 2006, 22, 45-51. [CrossRef] [PubMed]

122. Murooka, T.T.; Deruaz, M.; Marangoni, F.; Vrbanac, V.D.; Seung, E.; von Andrian, U.H.; Tager, A.M.; Luster, A.D.; Mempel, T.R. HIV-infected T cells are migratory vehicles for viral dissemination. Nature 2012, 490, 283-287. [CrossRef] [PubMed]

123. Calantone, N.; Wu, F.; Klase, Z.; Deleage, C.; Perkins, M.; Matsuda, K.; Thompson, E.A.; Ortiz, A.M.; Vinton, C.L.; Ourmanov, I.; et al. Tissue myeloid cells in SIV-infected primates acquire viral DNA through phagocytosis of infected T cells. Immunity 2014, 41, 493-502. [CrossRef] [PubMed]

124. DiNapoli, S.R.; Ortiz, A.M.; Wu, F.; Matsuda, K.; Twigg, H.L., 3rd; Hirsch, V.M.; Knox, K.; Brenchley, J.M. Tissue-resident macrophages can contain replication-competent virus in antiretroviral-naive, SIV-infected Asian macaques. JCI Insight 2017, 2, e91214. [CrossRef]

125. Orenstein, J.M. In vivo cytolysis and fusion of human immunodeficiency virus type 1-infected lymphocytes in lymphoid tissue. J. Infect. Dis. 2000, 182, 338-342. [CrossRef]

126. Haldar, M.; Murphy, K.M. Origin, development, and homeostasis of tissue-resident macrophages. Immunol. Rev. 2014, 262, 25-35. [CrossRef]

127. Amit, I.; Winter, D.R.; Jung, S. The role of the local environment and epigenetics in shaping macrophage identity and their effect on tissue homeostasis. Nat. Immunol. 2016, 17, 18-25. [CrossRef]

128. Lavin, Y.; Mortha, A.; Rahman, A.; Merad, M. Regulation of macrophage development and function in peripheral tissues. Nat. Rev. Immunol. 2015, 15, 731-744. [CrossRef]

129. Lee, C.Z.W.; Kozaki, T.; Ginhoux, F. Studying tissue macrophages in vitro: Are iPSC-derived cells the answer? Nat. Rev. Immunol. 2018, 18, 716-725. [CrossRef]

130. Verollet, C.; Souriant, S.; Bonnaud, E.; Jolicoeur, P.; Raynaud-Messina, B.; Kinnaer, C.; Fourquaux, I.; Imle, A.; Benichou, S.; Fackler, O.T.; et al. HIV-1 reprograms the migration of macrophages. Blood 2015, 125, 1611-1622. [CrossRef]

131. Van Goethem, E.; Poincloux, R.; Gauffre, F.; Maridonneau-Parini, I.; Le Cabec, V. Matrix architecture dictates three-dimensional migration modes of human macrophages: Differential involvement of proteases and podosome-like structures. J. Immunol. 2010, 184, 1049-1061. [CrossRef] [PubMed]

132. Li, Y.; Liu, T.M. Discovering Macrophage Functions Using In Vivo Optical Imaging Techniques. Front. Immunol. 2018, 9. [CrossRef] [PubMed]

(C) 2020 by the authors. Licensee MDPI, Basel, Switzerland. This article is an open access article distributed under the terms and conditions of the Creative Commons Attribution (CC BY) license (http://creativecommons.org/licenses/by/4.0/). 